\title{
河川の平均流速公式と河床面形態との関係について \\ ON THE RELATIONS BETWEEN MEAN VELOCITY FORMULAS \\ AND BEDFORMS OF RIVERS
}

\author{
杉尾捨 三 郎* \\ By Sutesaburo Sugio
}

\section{1. 平均流速公式に関する概説}

河川の平均流速公式の研究の歴史はきわめて古く, Chézy, Kutter, Manning, Bazin らの諸式は 80 100 年来親しまれている。ことに Manning 式は全世界で広 く愛用され, 固定床水路に対してはきわめて高く評価さ れているが，沖積河川などの移動床上の流れに対しては まだ不明確な点が多く残されている。一方, 洪水伝播理 論, 感潮河川論, 不等速流の背水計算, 平衡河床理論な ど, 流れの理論的取り扱い法は進歩したが，それらの理 論においてはほとんど Manning の粗度係数 $n$ は一定と して与えられたものとされており， $n$ の值そのものの研 究がかなり遅れていることは残念である。

戦後 $n$ のもつ流体力学的意義の解明が強調され, 河床 付近に発生する乱流境界層の粗さと河床不陸の規模とを 関連させようとする理論的研究が大いに発展した。これ らを仮に理論的方法とよぶことにする。このほか, Manning 式のように, 経験的に得られた指数形公式を 仮に経験的方法とよぶことにし，従来の諸研究の概略を 述べてみよう。

\section{(1) 理論的方法}

粗面乱流に対する流速の対数分布法則が移動床水路に 対しても成立すると考えると, 移動床表面の不陸と流速 分布式における粗度との関連を調べることによって, 平 均流速公式を理論的に導くことができる。Nikuradse は, 水路底面の粗さ $k$ と流れの摩擦抵抗係数 $f$ との関 係を調べて重要な法則を発見した。さらに Johnson,

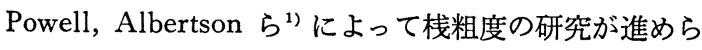
れ, わが国でも細井, 足立, 山岡らによって種々な形を もつ人工粗度の研究が行なわれた。Dune そのものの水 理学的研究が, 椿, Laursen, 松梨, Vanoni・Brooks, 芦

\footnotetext{
* 正会員 工博 德島大学教授 工学部土木教室
}

田・田中, 土屋・石崎らによって実施され，椿，Yalin， 松梨は dune の波長や波高を, 他の水理量と砂特性とか ら組みたられた無次元量を用いて表現しようと試みた。 一方, 現実の河川に発生する dune の規模の観測につい ては, Boyer の立体写真による測定, Rio Grande 河で 行なわれた Nordin の研究, 利根川で音響測深器を用、 て行なった建設省の研究などがある。

椿・古屋 ${ }^{21}$ は, 流れの平均流速公式を次式,

$$
\varphi=6.0+5.75 \log _{10} \frac{R}{k_{s}} .
$$

で表わしたときの相当粗度 $k_{s}$ を用い, 多数の自然河川 の資料から $k_{s} / d$ を掃流関数 $\psi$ で表わす一経験式を発 表した。ここに, $\varphi=V_{m} / v_{*}, V_{m}$ は平均流速, $v_{*}$ は摩 擦速度, $d$ は砂の粒径である。山口・松田ら ${ }^{3)}$ の検討に よると, 椿の方法による描点はかなり散在するが, dune を生じている緩勾配の河川に対して合理的であることが わかった。岩垣は平滑砂床の急勾配の実験水路の資料か

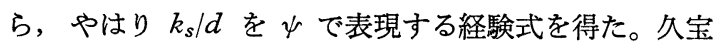
は, 玉石床上の流れについて $k_{s} / d$ の大きさを検討し ている。また椿・篠原らは $\varphi$ と $\psi \times \varphi /\left(6.0+5.75 \log _{10}\right.$ $\left.R / d_{m}\right)$ との関係を, 多くの九州河川について調べて図 を発表した。松梨や木下は, 実験室内で得られた資料を

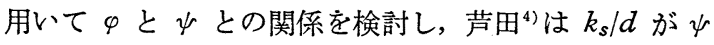
のみならずフルード数の関数であると述べ，細井 ${ }^{5)}$ は同 様の観点に立って，わが国の諸河川の $k_{s} / d$ をとつ ルード数とで表わそうと試みた。

他方, Manning 式の粗度係数 $n$ を, 水理量または砂 特性から直接簡単に定めようとする試みは, 古くは Strickler の公式 (11) に始まり, Chang もこれと類似 の式を発表している。Boyer は若干の河川を対象とし, $n / R^{1 / 6}$ を $R / d$ と $B / R$ との関数とする図を発表した。 ここに, $R$ は流れの径深, $B$ は水路幅である。杉尾は

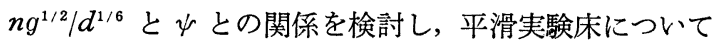
の一実験式を得た。 
つぎに特殊な考え方であるが, Einstein ら 代表される方法について述べよう。彼は径深 $R$ を 2 分 し, 砂粒摩擦による径深 $R^{\prime}$ と, 形状抵抗にもとづく径 深 $R^{\prime \prime}$ にわけ, $R$ ' の部分のみが流速の対数分布法則か ら定まる砂粒摩擦をうけ， $R$ ” をふくむ無次元量 $V_{m} /$ $\left(g R{ }^{\prime} S\right)^{1 / 2}$ と $R$ 'をふくむ掃流に関する関数 $1 / \psi$ 'との 関係を示す曲線を提案した。この有効摩擦速度を用いる 考え方は Colby \& Hembree, Laursen, Simons, 山岡, Yalin らに受けつがれ, 抵抗法則のみならず流砂量の研 究にまで発展した。たとえば Simons ${ }^{7)}$ は $R$ ”に相当す る水深 $D$ ”を, 勾配 $S$, 水深 $D$, および粒径 $d$ を用い て決定しようとし, 山岡 ${ }^{8)}$ は $R$ を 2 分する代りに摩擦抵 抗係数 $f$ を 2 分する方法を提案し, Yalin は損失水頭 を 2 分することにした。これらの諸方法のうち Simons のものは, かんがい水路の設計を対象とし, Einstein と 山岡の研究は自然河川を取り扱っている。Einsteinの方 法はアメリカではいまなお信頼度が高いことが Vanoni らによって述べられているが, 篠原・薄”が白川で実施 した研究によると, 彼の方法はあまりよく適合しなかっ たと報告されている。この理由の一つは, アメリカ河川 の河床材料の粒度は小さくて, ほぼ一様な場合が多いと 予想されるので, 実験室内において実際河川の河床形態 を再現しやすいが，わが国の河川では一般に河床材料が 粗大で, かつ細粗の混合範囲が大きいためであろうと思 われる。

\section{（2） 経験的方法}

一方, 流体力学的検討に重点をおくことを止め, むっ ぱら実用本位の平均流速公式を求めようとする努力が, 約 80 年前から河川技術者らによって長年続けられてき た。インド地方の運河の研究から始められた, いわゆる Regime Theory は, 流砂を伴う河川が長年月にわたっ て洗掘も堆積も起こさぬ, いわゆる stable な状態に達 したとき, 流量, 河幅, 水深, 勾配, 河床材料特性, 浮 遊砂量などの諸量間に存在する法則を, 実際河川の多く の測定資料から 推定しようとするもので, Kennedy, Linsley, Lacey, Lane, Blench らが代表的な研究者であ る。いま径哚を $R$, エネルギー勾配を $S$ とするとき, 流れの平均流速 $V_{m}$ を

$$
V_{m}=K R^{a} S^{b}
$$

で示すことにすれば, Manning 式では $K=1 / n, a=2 / 3$, $b=1 / 2$ である。 $V_{m}, R, S$ などの多数の実測值を利用 し, 定数 $K, a$ および $b$ を最小自乗法で求める方法が 多く行なわれてきたが，ここで注目したいことは，Sの 指数 $b$ として 0.5 よりかなり小さい值が多く発表され ていることである。

まず Humphreys と Abbot (1861) は Mississippi
河に対し, $K=5 \sim 5.7, a=0.5, b=0.20$ を与えており, Hagen (1876) は $K=3.34, a=0.5, b=0.20$ と更正し た。Lacey (1934) はさらに次式を提案した ${ }^{10)}$ 。

$$
V_{m}=16.0 R^{2 / 3} S^{1 / 3}
$$

( $\mathrm{ft}-\mathrm{sec}$ 単位)

その後, 彼は (1946) $a=0.5\left(1+n^{\prime}\right), b=n^{\prime}$ を提案し,さ らに最近 $a=5 / 8, b=1 / 4$ を発表し, 砂床に対しては $K$ $=9.5$, 石れき床に対しては $K=14.22$ を与えている ${ }^{11}$ 。 また Malhotra (1939) は $K=18.18, a=0.63, b=0.34$ を与え, Inglis (1941) は $K=12.0, a=4 / 7, b=2 / 7$ を 提案した ${ }^{12)}$ 。永井 (1941) は遼河などの満州河川を対象 として次式を発表した ${ }^{13)}$ 。

$$
V_{m}=\frac{1}{n_{k}} R^{0.55} S^{0.20}
$$

(m-sec 単位)

ここに， $n_{k}$ は砂れき係数とよばれ，河床砂れきの粒度 から推定せねばならない。のちに椿 (1951) は永井公式 を相当粗度の観点から説明し, 自然河川では $a=0.55$, $b=0.30$ 程度となるのであろうと述べた。久宝 (1955) は Lane や Strickler が砂利河川に対して与えた $\varphi$ の 值を検討し，玉石上の流れに対して $a=0.50, b=0.323$ を提案した ${ }^{14)}$ 。 Liu と Hwang ${ }^{15)}$ は室内実験資料を整理 することにより， $K, a, b$ などの定数が砂粒径 $d$ や流 砂面形態により変化することを確かめ, 一連の図を発表 しているが，自然河川の資料を含んでいない点が惜しま れる。Simons (1960) は Lacey の式 (3) にならって, $V_{m}$ と $R^{2} S$ との関係を 4 種の canal について検討した 結果, 河床と河岸の土砂特性により,つぎに示す 3 種の 経験式を発表した ${ }^{16)}$ 。

$$
\begin{gathered}
\text { coarse non-cohesive : } \\
V_{m}=17.9\left(R^{2} S\right)^{0.286}
\end{gathered}
$$

sand beds and cohesive banks :

$$
V_{m}=16.0\left(R^{2} S\right)^{1 / 3}
$$

sand beds and banks :

$$
V_{m}=13.86\left(R^{2} S\right)^{1 / 3}
$$

(ft-sec 単位)

このうち式 (6) は Lacey の式 (3) こ同一である。 $\mathrm{Garde}^{17)}$ らは次元解析の結果から Manning の式と同形 の式を導きただ粗度係数 $n$ を $n=K^{\prime} d^{1 / 6}$ とおき, Ripple と Dune に対しては $K^{\prime}=1 / 3.2$, Transition に 対しては $K^{\prime}=1 / 6.0$ を得ている。また $V_{m} /\left\{\left(\Delta \gamma_{s} / \rho_{f}\right)\right.$ $R\}^{1 / 2}$ と $(R / d)^{1 / 3} \cdot\left\{S /\left(\Delta \gamma_{s} / \gamma_{f}\right)\right\}$ との関係を示す図を利 用することを提案しているが，根本的には Manning 式 を変形したに過ぎないので, その信頼性はあまり期待で きない。

以上を要約すると, まず (1)の理論的方法の前半に述 べた諸研究は,いまだ実験室内の研究の段階であって,固 
定床とみなされる状態以外では現実の河川 に適用するまでに至っていないようであ る。(1) の後半に述べられたものの多く は，実際の河川を対象としているものが多 いが，そのうち椿式 (1) はかなり実用的で あると信じられている。Einsteinの方法は アメリカでは高く評価されているようであ るが，河床材料が細粗，いりまじっている わが国河川に対しては適用しにくい欠点が ある。（2）で述べた経験式は，元来個々の 河川に忠実に適応するように定数を定めら れたものであるから，普遍性に乏しい欠点 がある。

さて河川の平均流速は, 単に $R$ と $S$ のみの関数では なく, それ以外に多くの複雑な要素の支配をうけるもの と思われる。また，エネルギー勾配の代りに水面勾配を 使わざるを得なかったり，また流速測定そのものの精度 も一様ではない。このように観測資料にも誤差が加わる から，個々の河川の観測資料に忠実であればあるほど， 無数の経験式が発表されることになる。

そこで本研究では，むしろ巨視的に平均流速公式を眺 めることにより，なるべく多数の河川に普遍的な傾向を 把握することに重点をおいて解析を進めた結果, 3 種の 典型的な群が存在することが明らかになった。さらに著 者が別に提案した流砂面形態の区分図を利用することに より，それぞれの群の河床形態をおよそ推定することが 可能となった。

\section{2. 新平均流速公式の提案}

従来用いられてきた Manning 式が，自然河川に対し どの程度に適合するかを検討するため, 両対数紙の両軸 上に $V_{m}$ と $R^{4 / 3} S$ をとり, 日本, 満州, インドなどの 諸河川の資料を点描したのが 図一1 である。ここに $S$ はエネルギー勾配であるが，資料が十分得られないので 単に水面勾配を用いた。また径墚 $R$ は流積 $A$ を水面

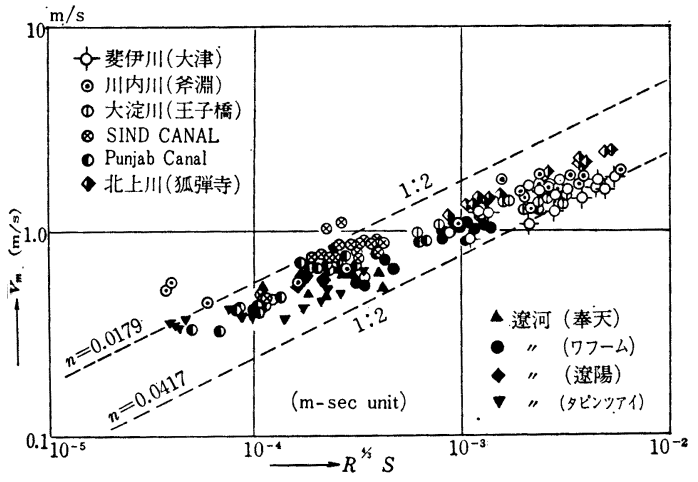

図一1 $V_{m}$ と $\boldsymbol{R}^{\mathbf{4} / \mathbf{S}}$ との関係（第(1)群河川)

幅で割って求めたものである。さて図一1に拈いて，水 平軸と $1 / 2$ の勾配をむつ直線が Manning 式を示すこと になるから，図上の 2 直線にはさまれた帯状部の幅が 1/n の変動範囲を示している。すなわちこの資料では, $n$ の変動範囲は $0.0179 \sim 0.0417$ であった。

元来, 河川の平均流速は主として径深 $R$ と勾配を最 も重要な変数としているが, その他河床砂れきの大き さ，砂れきの大小粒の混合状態，断面内の配列，水路の 断面形状, 護岸や植生の有無, 浮遊土砂の影響など, 多 くの要素に支配されるはずである。したがって，描点の 散開が相当大きいことも当然であるが, しかし描点の散 開ができるだけ小さくなるように $R$ と $S$ との指数を選 ぶことが望ましい。

そこでいま Lacey や Simons ${ }^{18)}$ が試みたように, $V_{m}$ と $R^{2} S$ とを両対数紙の両軸にとり，できるだけ多くの 河川の観測資料を点描したのが 図一2である。描点はか なり散開してはいるが，巨視的にみると 2 種の群に分類 されるように思われる。(1)群とかかれた直線の周囲に集 まる描点は, さきの図一1 に示された諸河川の資料から そのまま点描したもので, $V_{m}$ の変動幅は Manning 式 を用いたときの半分以下となり, 集中度はかなり改善さ れる。描点を代表する直線を肉眼で適当に描くと次式が 得られる。

\section{(1) 第(1)群河川}

第(1)群: $V_{m}=54 R^{0.54} S^{0.27}$ ( 8 ) (cm-sec 単位)

この群に属する河川の勾配は, 大体 $1 / 1000$ 以下程度の 緩やかな流れで, 河床砂の平均粒径は $2 \mathrm{~mm}$ 以下のもの が多かった。図一3 は,永井が調査した満州の 4 河川 ${ }^{19}$ に ついて,式 (8) の係数 $K$ と Manning の粗度係数 $n$ の 值とを, 単位幅あたりの流量 $q$ を横軸として点描したも のである。図より明らかなように，Kの変動幅は $n$ の それに比してかなり小さく，K=54 のまわりに描点が 

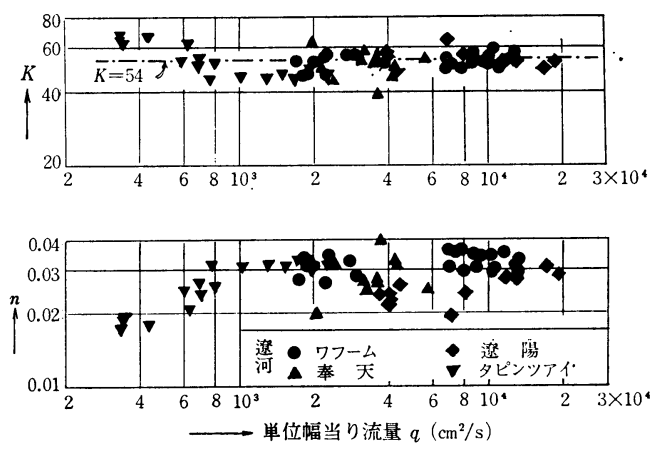

図一3 K および $n$ の流量に対する比較（遼河）
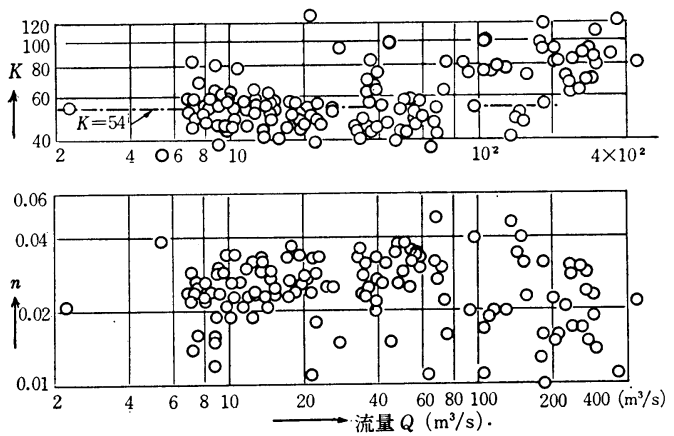

図一4 $K$ および $n$ の変動（白川長六橋）

集中している。インドの 2 河川の資料 ${ }^{20)}$ は同一の測水地 点で得られたものではなく，したがって断面形も砂の粒 径もそれぞれ異なるが，大体式 (8) のまわりに描点が集 まる。白川長六橋付近の粗度係数 ${ }^{21)}$ に関してはさきに策 原・薄が詳細な研究を発表し ${ }^{22)}$, Einstein らの方法はか なり誤差が大きいこと，また椿の方法を用いて $k_{s} / d_{50}$ の值を検討した結果, 流量が $100 \mathrm{~m}^{3} / \mathrm{sec}$ 以下のときは 椿式がほぼ成立すると述べた。図一4 は, 式 (8)の $K$ と流量 $Q$ との関係を点描したもので， $Q<60 \mathrm{~m}^{3} / \mathrm{sec}$ の範囲内ではほぼ $K=54$ のまわりに描点があると考え られ，篠原らの結論を裏書きしている。しかし $Q>60$ $\mathrm{m}^{3} / \mathrm{sec}$ の範囲では描点は散開しすぎて 結論が得られな かった。この部分では $Q$ の増加とともに 河床抵抗が減少する傾向がみられるが，大 洪水時の資料のなかには，極端に水面勾配 の小さいものが多くみられ，これが描点の 散開を大きくしているようである。北上川 と川内川の場合 ${ }^{23)}$ には, 河床の平均粒径が $10 \mathrm{~mm}$ 以上もあったが, 洪水時の描点は大 体第(1)群に属した。

注意すべき点は，図一2 において $R^{2} S>$ 25 の範囲に対しては，描点が式 (8) より もやや急傾斜をもつ別の直線の周囲に集ま るように思われる傾向も存在するようで, とくに北上川の例にみうけられる。この点
に関しては，将来一層多くの河川資料を用いることによ り，しだいに明らかになるものと考える。

\section{（2）第(2)群河川}

図一2上には第(2)群に属する資料も点描されている が，これらの河川の勾配は $1 / 1000$ 程度より急で，かつ 河床材料は砂利以上程度に相当する。描点の散開は第(1 群の場合よりかなり大きいが，概略的にいえば，およそ 次式の周囲に集まる。

第(2)群 : $V_{m}=80 R^{0.54} S^{0.27}$

(cm/sec 単位)

さてこの群に属するものは第(1)群に属するものよりも 河床抵抗が小さいはずで，式の形からみれば Simons の 式（5）にきわめて近い。河床粒径のかなり大きいU.S. B.R. の河川 ${ }^{24)}$, 犀川小市橋, San Luis Valley ${ }^{25)}$, 常願 寺川 ${ }^{26)}$ などの描点は大体式 (9) の周囲に集まるが，ここ でとくに注意すべきことは，河川によっては (1) から (2) へ，または(2)から(1)への「移行現象」が認められること である。たとえば球磨川（白石）や千曲川（杭瀬下）の 描点は, 洪水による増水に伴って第(2)群から第(1)群へ移 行し, この区間では水深が増加しても $V_{m}$ はほとんど変 化していない。この理由は，この区間ではおそらく河床 面形態の変化がおこり, 流水による抵抗が増加するため であろうと推察される。なお犀川 (小市橋) の場合に は, $\boldsymbol{Q}<80 \mathrm{~m}^{3} / \mathrm{sec}$ 程度の低水時の描点は第(1)群にある が，Q>150 m³ $\mathrm{sec}$ になると第(2)群に移るようと思われ， る。しかし低水時における水面勾配, 平均流速などの测 定精度に対しては十分な検討をしていないので, 低水時 の資料については確信をもって述べることができない。

\section{（3）第(3群河川}

図一5 は第(3)群に属するもの, すなわち最も河床抵抗 の小さい, Upper Regime に属する描点のみを集めて みた。これらの河川では，水面勾配がかなり急であるか，

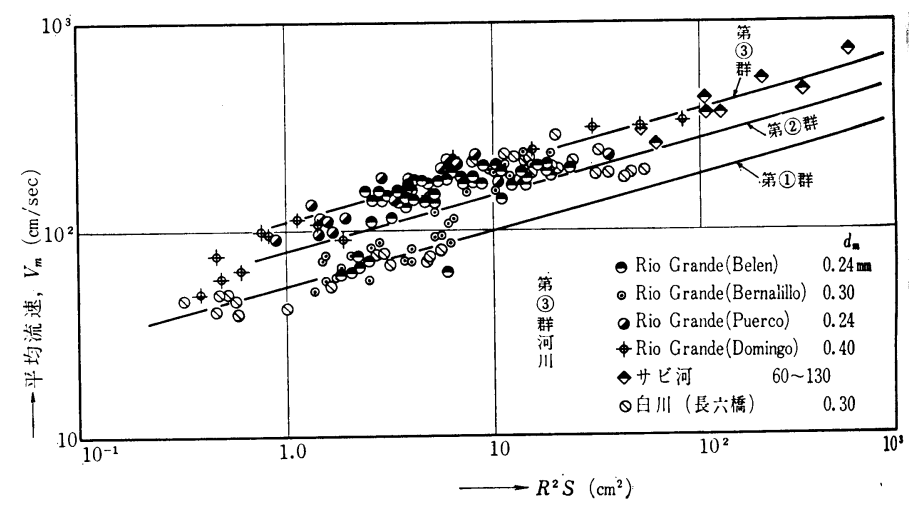

図一5 $V_{m}$ と $\boldsymbol{R}^{2} S$ との関係（第(3群河川） 
または勾配はさほど急でなくても河床材料が $0.2 \sim 0.3$ $\mathrm{mm}$ 程度の細砂で構成されており, かつ洪水量が大きい 場合に生じやすいと考えられる。Rio Grande 河の 4 地 点, サビ河 ${ }^{27)}$, 白川などがこれに属する。この群の河川 における野外実測はきわめて困難であろらから, 精度も あまり期待できないが, 無理に式で表わせば式 (10) が 得られる。

第(3)群: $V_{m}=110 R^{0.54} S^{0.27}$

(cm-sec 単位)

Rio Grande 河の例では河床砂は細砂で, 勾配は Domingo 地点では $1 / 250$, その他では $1 / 1000$ 内外で あった。いま Belen 地点の描点をみると, 流量の小さ 、区域では第(1)群にあったものが流量の増加とともに第 (3)群に移行し, さらに $Q$ がますとやや流水抵抗が増加 し, 第(2)群と第(3)群の中間に落ちつくことがわかる。白 川の例ではあまり明確ではないが， $Q>200 \mathrm{~m}^{3} / \mathrm{sec}$ に対 しては(3)群も少々あるし, また(2)群に近いものも存在す るようである。以上の傾向は拉そらく，河床が Transition から Antidune 一移行する過程を示すものではな からうかと察せられる。サビ川で得られた木下の貴重な 資料では勾配は $1 / 100$ 以上で, 河床材料は大砂利程度で あったと報告されている。大体第(3)群の線に沿うて変化 するものとみられ, Rio Grande 河のような描点の下降 部をもっていないのが特色である。結局, サビ川の場合 の $K$ の值は 110 程度であるが, Rio Grande 河のよう に河床材料が微細砂で流量が大きいものに対しては，K の値は 110 程度からしだいに減少し, Antidune になる にしたがって 80 に近くなる。

最後に砂れきが限界掃流力以下の状態にある場合の平 均流速公式について若干ふれておく。いわゆる固定床と みなされる場合には一般に Manning-Strickler 公式,
式を巨視的に分類すると 3 種類に分類され，それらは勾 配, 流量, 河床砂の粒度などと深い関係があると推定さ れる。さて河床表面には Ripple, Dune, Antidune など の河床形態が生ずることは早くから知られ，水理量と河 床材料特性との組み合わせにより河床面形態を規定する 方法はすでに, Gilbert, Langbein, Liu, Bogardi, 杉 尾, Garde-Albertson, Garde, Simons, Kennedy, 林ら の多くの研究者によって提案されてきた。河床抵抗は当 然河床面形態によって変化するはずであるから, 平均流 速公式と河床面形態との関係を調べることには重要な意 義がある。

\section{（2） Garde の区分図と平均流速公式との関係}

Garde $^{29)}$ は自己の発表した 流砂面形態の区分法と Manning 系の平均流速公式との関連を検討 し, $n=$ $K^{\prime} d^{1 / 6}$ とおいた場合, Ripple とD Dune に対しては $K^{\prime}$ $=1 / 3.2$, Transition に対しては $K^{\prime}=1 / 6$ を得ている が，自然河川の資料はほとんど用いられておらず，実験 室内の資料を中心とした研究であるのが惜しまれる。本 論文ではまず Garde の区分法と $V_{m}=K\left(R^{2} S\right)^{0.27}$ 式と の関係を調べ，つぎに著者が最近提案した区分法と上述 の平均流速公式との関係を検討してみよう。

図一6は，Garde の表示にしたがい，両対数紙の縦軸 には $S /\left(\Delta r_{s} / r_{f}\right)$ を，横軸には $R / d_{m}$ をとり，この論文 に引用されたすべての河川資料を点描してみた。ここに $\Delta \gamma_{s} / r_{f}$ は砂れきの水中比重, $d_{m}$ は平均粒径であるが, ここでは $d_{65}$ を用いている。

さて全般としてみると Garde の表示は大体満足すべ きものであるが，詳細に検討すると若干不合理な部分が 存在する。まずさきの平均流速公式の第(1)群と示された 資料の大部分の描点は, Garde の図の Ripple と Dune

$$
n=0.016 d^{1 /}
$$

$(d: \mathrm{mm})$

が成立すると考えられている。細井 ${ }^{28)}$ は わが国の若干の河川について $n$ の值を調 查した結果，固定床状態において $n$ をほ ぼ一定とみなしても差しつかえない河川 例をあげている。著者はとくに低水量の 場合について $V_{m} \sim R^{2} S$ の関係を求めよ うと試みたが，描点が極端に散開するた わ結論を得ることができなかった。

\section{3. 河床面形態 と 平均流速公式と の関係}

(1) 概 説

以上述べたように，河川の平均流速公

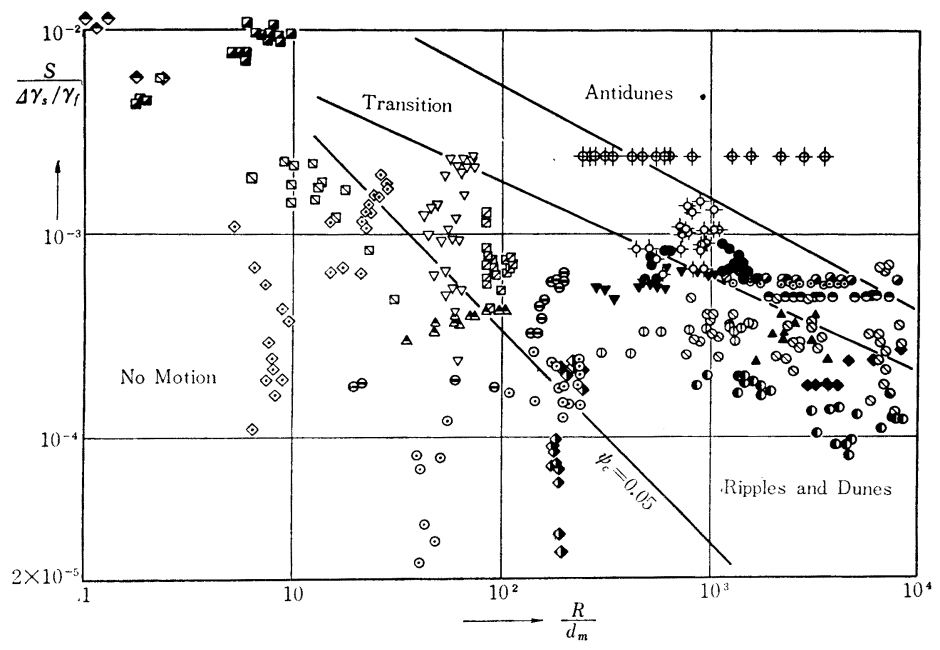

図一6 Garde の方法による河床形態区分図（自然河川） 
の共通の領域内に含まれているのは合理的ではあるが， 斐伊川と遼河 (ワフーム) の描点の大部分が Transition の領域内に含まれることになって不都合である。その理 由は, Transition とは河床抵抗のかなり小さい状態を示 すべきであるのに，第(1)群は，河床抵抗の最も大きい場 合を示すはずであるからである。また Rio Grande 河の Domingo 地点の資料は，平均流速公式から推定すると 第(2)群から第(3)群までの広、範囲を占めるはずであるの に，図一6によれば Dune の領域の描点を見いだすこ とができない。

なお Garde は Dune と Ripple を同一の領域内のも のと考えたのであるが，図一6 をみれば第(1)群の描点は その領域の下部に, 第 2 群の描点は大体その領域の上部 に集中することが明らかである。これから判断すると， 第(1)群の河床面形態はおそらく Ripple, 第(2)群のそれは Dune であろうと察せられる。

\section{（3） $S \sim q / w d_{m}$ 区分図と平均流速公式との関係}

さて著者は Garde の方法とは別に，新たに勾配 $S$ と $q / w d_{50}$ を両対数紙の両軸にとる 河床面形態の区分法を 提案し ${ }^{30)}$, 主として Gilbert と Simons の室内実験資 料を用いて各レジムの区分線を描いたが，これを自然河 川の場合に応用したものが図一7である。ただし，自然 河川の場合には $d_{50}$ の代りに平均粒径 $d_{m}$ を用いて $q /$ $w d_{m}$ を求めた。ここに $q$ は単位幅あたりの流量で, $w$ は粒径 $d_{m}$ の砂粒の静水中の沈降速度である。w の計 算はアメリカ土砂委員会の推奖する方法 ${ }^{31}$ にしたがうこ とにした。砂粒の shape factor を 0.7 とみなして沈降 粒径を求め, 水温を $20.3^{\circ} \mathrm{C}$, 砂比重を 2.65 と仮定して wを図から読みとった。フルイ粒径が $10 \mathrm{~mm}$ 以上のも

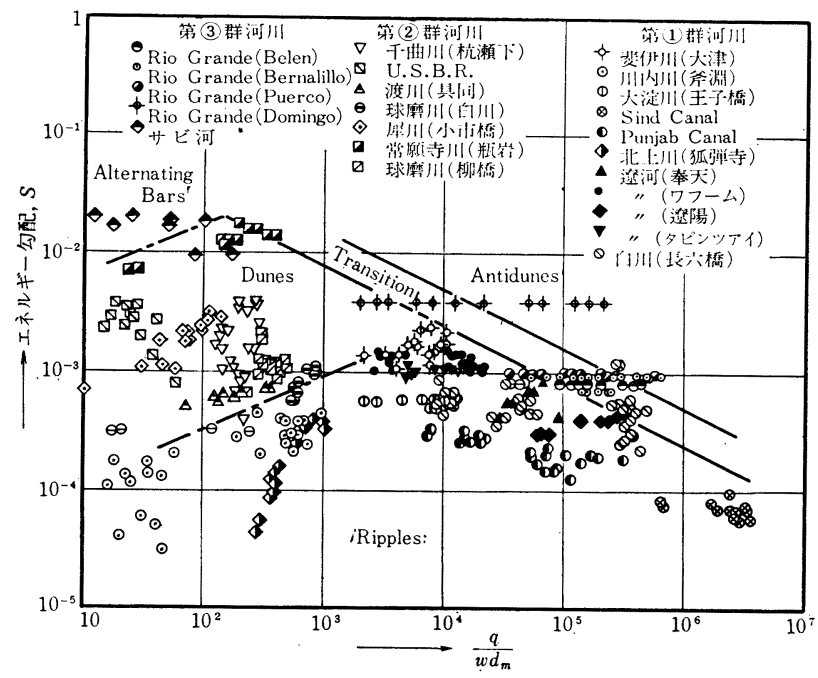

図一7杉尾の方法による河床形態区分図（自然河川）

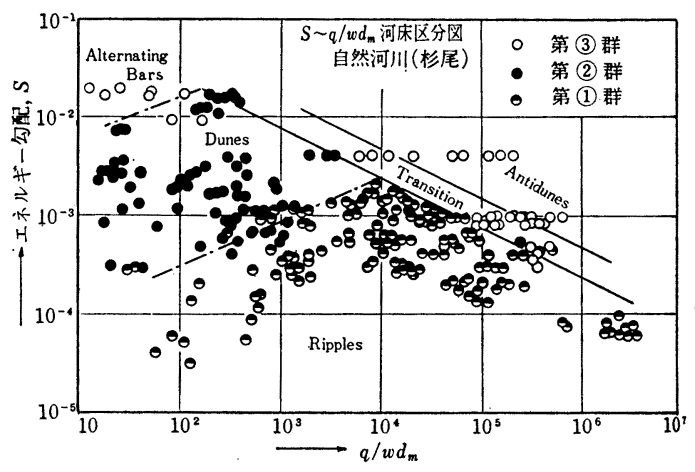

図一8 平均流速公式と河床形態との関保図（自然河川）

のについては $S . F .=0.7$ の線を図上で外挿することに し，またとくにdが大きいときには Rouse が示した形 状抵抗係数 $C_{D}$ と $R_{e}=w d / \nu$ の関係図を用い, 試算に より wを定めた。

図一8 は上述のすべての河川の描点を各群ごとに分類 して表示したものである。ただし 図一2，図一5 におい て, 所属する群の判別がかなり明瞭な資料のみを点描し ている。図一8 をみれば，各群ごとにそれぞれ固有の領 域をもつことが認められ，すなわち図の下部には第(1)群 が，その左方上部には第(2)群が，また最上部および右方上 部には第(3群の描点が集中する。第(3)群を区分する 2 本 の実線は，さきに著者が実験室内の資料に対して $S \sim q$ $w d_{50}$ 図を適用した結果, Transition および Antiduen の境界線として描いたものと全く同一である。また図上 で鎖線で示された 2 本の境界線は，各群を概略分割する ように肉眼で判定して適宜描かれたもので，その位置は 室内実験資料汶する区分図の各境界線の位置とは若干 異なるのではあるが，両図を比較することによって，第 (1)群の河床面形態は Ripple, 第(2)群のそれは Dune, 第(3)群のそれは Transition や Antidune を含めた Upper Regime に相当するものと推定 される。図一7, 図一8 から明らかなようにま ず斐伊川 ${ }^{322}$, 遼河の 4 地点の 描点は完全に第(1) 群，すなわち Ripple の領域内にあって，最も大 きい河床抵抗を与える。また Rio Grande 河の Domingo 地点の描点は第(2)群から第(3)群の Up. per Regime の領域にまで伸びており，図一2, 図 -5 と矛盾しない。Rio Grande 河の他の 3 地点 の描点も第(1)群から第(3)群の Upper Regime に まで拡がり，それぞれ Garde の表示によるもの より好結果を与える。

インドの Punjab Canal や Sind Canal の描 点は, 勾配が小さいので完全に第(1)群, すなわち Ripple の領域内にふくまれる。図一8において, Ripple と Dune の境界線付近は資料も少ないの 
で，境界の位置は確実なものではない。したがって今後 野外資料が豊富に入手できたならば，若干境界線の位置 は変化する可能性がある。

Garde は Ripple と Dune を同一の範ちゅうに含め， また Vanoni ${ }^{33)}$ や Kennedy らのように, 両者は規模 が異なるだけで水理学的には同一であるという説をもつ 研究者が若干ある。しかし上述のように, 抵抗法則の点 からみると Ripple と Dune とはかなり差異があるこ とが明らかで，この意味では Simons の説に同意するも のである。図一8 より明らかなように, Ripple は勾配 $S$ が緩やかな場合におこりやすく，Dune は勾配はか なり大で，かつ河床砂が大きいときに現われやすい。

図一8 の上部に常願寺川の描点がみられる。これらは 平均流速公式から検討すれば第(2群に属するもので図上 では Dune の領域になるように Transition との境界線 を鎖線で適宜描いたものである。したがってこの部分も 今後他の多くの資料を用いて検討を要する部分である。

サビ川の測定資料はわずか 8 個に過ぎないので, 精度 もあまり期待できないが，これらは最も河床抵抗の小さ いTransition の領域にふくまれることがわかる。木 下 ${ }^{34)}$ が, 砂れき堆に関して行なった実験值の大部分は, $S \sim q / w d_{50}$ 区分図上においても 図一8 の場合でも大体 同一の領域を占有した。従来急流河川で流速測定が実施 された例がきわめて少ないので, 今後砂防河川などでこ の種の測定が行なわれることを心から期待する。

\section{（4）限界掃流力を示す区分線}

Garde の区分図（図一6）は，限界掃流力を示す境界 が両対数紙上で $\psi_{c}=0.05$ の直線で表示される特徴があ る。そこで著者の提案する $S \sim q / w d_{m}$ 区分図上でも， このような直線が描けるかどうかを検討してみよう。ま ず限界掃流力状態における流れの抵抗法則として, 固定 床に対する Manning-Strickler 公式 (11) が成立するも のと仮定すれば, cm-sec 単位に書き直された Manning 公式は,

$$
V_{m}=197.6 R^{2 / 3} S^{1 / 2} d^{-1 / 6}
$$

となるから， $R=u_{* c}{ }^{2} / g S$ を用いて $q / w d_{m}$ を変形すれ ば

$$
\left.\begin{array}{l}
q / w \cdot d_{m}=C_{K} \cdot S^{-7 / 6} \\
C_{K}=197.6\left[u_{* c}{ }^{2} / g\right]^{5 / 3} / w d_{m}{ }^{7 / 6}
\end{array}\right\}
$$

となり, 平均粒径 $d_{m}$ が与えられると $C_{K}$ は定数とみ なされる。したがって限界掃流力を示す線は $S \sim q / w d_{m}$ 図上では一直線で表現できることになる。ここに $u_{* c}$ は 限界掃流力に対する流れの摩擦速度である。

いま岩垣 ${ }^{35}$ が 提案した限界掃流力公式が，平均粒径 $d_{m}$ の混合砂床をもつ自然河川に対しても成立するもの と仮定して $C_{K}$ の值を計算してみると， $C_{K}$ は $d_{m}$ に
より若干変化し，たとえば $d_{m}=1 \mathrm{~mm}$ に対しては $C_{K}$ $=0.04, d_{m}>3 \mathrm{~mm}$ の範囲に対しては $C_{K}=0.068$ が得 られる。このように $C_{K}$ が粒径に応じて若干変化するこ とは結局 $S \sim q / w d_{m}$ 区分図上で限界掃流力線が平行に 若干移動することになり，Gardeの表示法よりも不便な 点である。しかし自然河川の砂れき粒度の特殊性を考え ると，つぎに述べるように，平均粒径を基礎においた限 界掃流力状態の設定そのものに若干の疑念が存在すると 思われる。

すなわち，いま河床が平均粒径 $d_{m}$ にひとしい大きさ の砂粒のみから構成されているものと仮定し, それに相 当する限界掃流力を計算したとしても, その状態のもと では実際の河床上において， $d_{m}$ より小さい粒度の砂粒 はさかんに移動しつつあると思われる。したがって, こ の状態は真の限界掃流力状態を規定したことにはならな い。図一7をみても，平均流速公式の各群は式 (13) で表 わされる限界掃流力の線とは全く無関倸のように思われ る。実験室内の流砂面の形態を研究する場合のように,砂 粒の標準偏差が小さく，ほぼ均一に近い状態ならば限界 掃流力線の決定は大いに意味があるが, 砂れき粒度の標 準偏差のきわめて大きい自然河川に対しては，限界掃流 力線の決定にあまりカをそそぐ必要はないと思われる。

以上述べたように，河床砂れきの粒度が大小きわめて 広、範囲に分布している場合には，それが Ripple や Dune の形成限界にも当然影響することが予想される。 $S \sim q /$ wd 区分図を用いたとき，Ripple と Dune の境 界線の位置が自然河川と室内実験とでは若干異なること も，以上の理由によるものであろう。しかし，Transition と Antidune の部分の境界線の位置は, 両者とも 全く同一であったことは前述した。この理由はおそらく， 流れが Transition や Antidune の状態になると,大粒の 砂れきも小粒の砂も区別なく流送されるようになり，標 準偏差の影響が小さくなるためであろうと推察される。

著者 ${ }^{36)}$ はさきに均一粒砂に関する掃流流砂量の検討を 行なったとき, Simons らによる混合粒砂の流砂量は, Ripple や Dune の状態の場合には均一粒砂の流砂量よ りかなり減少するが, Transition や Antidune の状態 になると，均一粓も混合粒もほぼ同一の流砂量を与える と述べた。結局 Ripple や Dune の形成限界と流砂量 は，砂粒の混合状態に影響するが，Transition や Antidune に対するそれは砂粒の混合状態に無関係になる こととなり,きわめて興味深い。

\section{（5）種々な平均流速公式の比較}

$V_{m}=K R^{a} S^{b}$ の形をもつ代表的な平均流速公式を一覧 にしたのが 表一1 である。また著者が提案した式 (8)， (9)，(10）を ft-sec 単位に書き直すと次式になる。 
表一1 平均流速公式の比較 (ft-sec 単位)

\begin{tabular}{|c|c|c|c|}
\hline 研 究 者 & 年度 & 河林区 分 & 平均流速公式 \\
\hline Lacey & 1934 & & $V_{m}=16.0\left(R^{2} S\right)^{0.333}$ \\
\hline Inglis & 1941 & & $V_{m}=12.0\left(R^{2} S\right)^{0.286}$ \\
\hline Simons & 1966 & $\begin{array}{l}\text { (a) 粗 い砂 床 } \\
\text { (b) 砂床, 土護岸 } \\
\text { (c) 砂床, 砂護岸 }\end{array}$ & $\begin{array}{l}V_{m}=17.9\left(R^{2} S\right)^{0.286} \\
V_{m}=16.0\left(R^{2} S\right)^{0.333} \\
V_{m}=13.86\left(R^{2} S\right)^{0.333}\end{array}$ \\
\hline Lacey & 1966 & $\begin{array}{ll}\text { 砂 } & \text { 床 } \\
\text { 砂れき床 }\end{array}$ & $\begin{array}{l}V_{m}=9.5\left(R^{2.5} S\right)^{0.25} \\
V_{m}=14.22\left(R^{2.5} S\right)^{0.25}\end{array}$ \\
\hline 杉 & 1969 & $\begin{array}{l}\text { (1) Ripples } \\
\text { (2) Dunes } \\
\text { (3) Transition }\end{array}$ & $\begin{array}{l}V_{m}=11.2\left(R^{2} S\right)^{0.27} \\
V_{m}=16.6\left(R^{2} S\right)^{0.27} \\
V_{m}=22.9\left(R^{2} S\right)^{0.27}\end{array}$ \\
\hline
\end{tabular}

第(1)群 (Ripple) : $V_{m}=11.2 R^{0.54} S^{0.27}$

第(2)群 (Dune) : $V_{m}=16.6 R^{0.54} S^{0.27}$.

第(3)群 (Transition) : $V_{m}=22.9 R^{0.54} S^{0.27} \cdots(16)$

\section{( $\mathrm{ft}$-sec 単位)}

図一9 はこれらの式を $\mathrm{ft}-\mathrm{sec}$ 単位を用いて比較した ものである。図から明らかなように, Simons の式 (6), すなわち初期の Lacey の式は Inglis の式とほと んど同一の傾向をもち, Simons の式 (c) はこれよりや や河床抵抗が大きい。この中間を縫って杉尾の第(1)群の 公式がきわめて広範囲の $R^{2} S$ の值に対して成立するこ とを考えると，巨視的にみれば Simons の式 (b)，(c)， および Inglis の式は Ripple 河床に対応するものであ ると想像される。また Simons の式 (a) は杉尾の第(2) 群公式とほとんど同一であるから, Simons（a）の河床 は Dune 河床であると推定される。また Lacey が 1966 年に発表した公式は $V_{m}=K_{0} R^{5 / 8} S^{1 / 4}$ の形をもつため, 図一9上で表現できなかったが，おそらく一方は Ripple を,他方は Dune bed を示すものであろうと推定される。

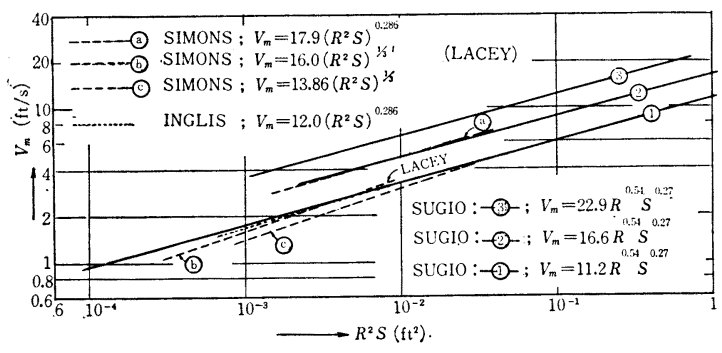

図一9種々なる経験式の比較図

\section{（6）計 算 例}

単位幅あたりの流量, $q=1.569 \mathrm{~m}^{2} / \mathrm{sec}$, 勾配 $S=1$ / 1450 , 河床砂の平均粒径 $d_{m}=0.796 \mathrm{~mm}$, 砂比重 $\sigma / \rho=$ 2.60 が与えられたとき, 平均流速および径深を定めよ (肝属川 ${ }^{37)}$ の例)。

(解) フルイ粒径 $=0.769 \mathrm{~mm}$, shape factor $=0.70$ と して図 ${ }^{38)}$ より沈降粒径 $=0.69 \mathrm{~mm}$ を求める。U.S. Dept. of Agriculture による図を利用し，水温を $20^{\circ} \mathrm{C}$ と仮定 して $w^{\prime}=10.7 \mathrm{~cm} / \mathrm{sec}$ を求める。比重の相違による更 正には近似的に次式を用いることにしよう。

$$
w=w^{\prime} \sqrt{\frac{\sigma / \rho-1}{2.65}}
$$

ここに $w, w ’$ はそれぞ砂比重が $\sigma / \rho$ ，および 2.65 で ある場合の砂粒の沈降速度である。さて $\sigma / \rho=2.60$ であ るから式 (14) より $w=10.54 \mathrm{~cm} / \mathrm{sec}$ を得る。これよ り, $q / w d_{m}=1.569 \times 10^{4} / 10.54 \times 0.0796=1.87 \times 10^{4}, S$ $=0.690 \times 10^{-3}$ 。これを 図一8 上に点描すれば第(1)群の 領城内におちるので, 式 (8) より $K=54$ と決定する。 さて $q=R \cdot V_{m}$ とみられるので, 式 (8) を代入すれば,

$$
R^{1.54}=\frac{1.569 \times 10^{4}}{54} S^{-0.27}
$$

上式に $S$ の值を代入して $R$ を計算すると $R=142.5$ $\mathrm{cm}$ が得られ, $V_{m}=q / R=1.569 / 1.425=1.101 \mathrm{~m} / \mathrm{sec}$ と なる。

（注）実測の平均流速は $1.039 \mathrm{~m} / \mathrm{sec}$ であったから， 結局 $5.81 \%$ の誤差となった。

\section{4. 結言}

河川に対する Manning の粗度係数 $n$ には明確な点 が多いので ${ }^{39)}$ ，本論文はこれに代るための河川の平均流 速に関する一経験式を提案したものである。

（1）国内，国外の諸河川の実測資料を利用して検討 した結果, 平均流速公式は大略つぎの 3 種の群に分類さ れることが明らかになった。すなわち，

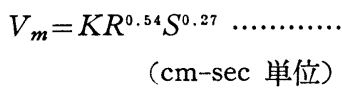

とするとき，第(1)群では $K=54$ ，第(2)群では $K=80$, 第(3)群では $K=110$ となった。

（2）図一2, 図一5 にみられるように，水位または 流量の増加と共に, 一方の群から他方の群へ『移行』す ることがあり，この際河床面形態の変化が予想される。

(3) $S \sim q / w d_{m}$ 区分図を利用して, 河床面形態と平 均流速公式の各群との関係を検討した結果, 第(1)群の河 河床面形態は Ripple, 第(2)群のそれは Dune, 第(3)群の それは Transition に相当すると推定される。

(4) 従来 Ripple と Dune とは水理学的には同一 の性質をもつとの考えがあったが，図一8にみられるよ らに両者の河床抵抗はかなり異なるものである。

（5）砂れき堆河川の抵抗法則は第(3)群，すなわち Transition の式で表わされる。また河床砂が 細砂で流 量の大なる 河川では, 河床面形態が Transition から Antidune に変化するとともに，K の值は減少して 110 から 80 に近づく傾向がみられた。

（6）河床材料の粒径の標準偏差がきわめて大きい場 
合は, 実験室内の砂のようにほぼ均一粒の場合にくら べ，流砂面形態を規定する水理条件が若干異なる。わが 国の河川のように，河床砂れきが大小広範囲に混合して 、る場合には，限界掃流力の条件を規定することは困難 である。

（7）河川の水理量 (流量, 河幅, エネルギー勾配) と河床材料の特性 (平均粒径, 比重, 形状係数) が与え られると，まず図一8を用いることにより，その描点の 位置からどの群に属するかを推定することができる。つ ぎに式 (15) より妥当な $K$ の值を求めれば平均流速公 式が定まることになる。

河川の平均流速は $R$ と $S$ とを最も重要な変数として いるが,その他河床砂れきの粒度, 大小粒の配合状態,水 路断面内の配列状態, 水路の横断面形状, 護岸の種類, 植物の生育状態, 浮遊土砂の影響など, 多くの複雑な変 数を含む ${ }^{40)}$ はずであるから，式 (18) における係数 $K$ の 值については，今後なおいっそうの検討を要する。

謝辞 : 資料の多くは建設省, 各地方建設局が長年苦心 して観測し整理されたもので，貴重な資料の利用を許さ れた関係各位のご厚意に深謝する。また Colorado 州立 大学の Simons 教授のご協力とご助言に対して深く感謝 する。計算と図面の作製には徳島大学工学研究科 堀勝 也氏の協力を得た。この研究は文部省科学研究費, およ び災害科学特定研究費を支給されて実施されたことを付 記し，関係各位に感謝する。

\section{参 考 文 献}

1）足立昭平：流れの抵抗法則；水工学に関する 夏期研修会 講義集, 河川コース, 1967, pp. 02-8.

2）椿東一郎・古屋朝治：流砂ある河川における 流速法則に ついて, 九大流体力学研究所報告, 第 7 巻第 4 号, 1951 , pp. 8-24.

3）山口高志・松田芳夫：移動床水路の粗度について，第 18 回建設省技術研究報告, 昭 39,11, pp. 469-477.

4）芦田和男：河川の粗度について，土木技術資料，第 1 巻 第 7 号, 1959, pp. 8-10.

5）細井正延：河川急流部の粗度係数と 河道計画との 関連に ついて, 建設省土木研究所報告, 115 号の 1, 1962, pp. 1-79.

6) Einstein, H.A. \& Barbarossa, N.L. : River Channel Roughness, Proc. ASCE, Vol. 77, No. 78, July 1951, pp. 1-12.

7) Haynie, R.M. \& Simons, D.B. : Design of Stable Channels in Alluvial Materials, Proc. ASCE, Vol. 94, No. HY 6, Nov. 1968, p. 1405.

8）山岡 勲：自然河川の粗度に関する一考察, 北海道開発 局土木試験所報告; 第 27 号, 昭 37.3, pp. 57-66.

9）篠原謹爾・薄 慶治：長六橋付近の 白川の 粗度係数につ いて, 九大応用力学研究所報, 第 7 号, 昭 30,9, pp. 2738.

10) Lacey, G. : Stable Channels in Alluvium, Proc. Inst. Civ. Engrs., Vol. 229, (1929-1930), p. 259.

11) Lacey, G.: Discussion for "Stable Channels with Gravel-paved Beds" by R. Kellerhals, Proc. ASCE, Vol. 93, Nov. 1967, pp. 248-250.

12) Chow, V.T. : Handbook of Applied Hydrology, Mc-
Graw-Hill Book Co. New York, 1964, p. 7-27.

13）永井荘七郎：移動床を有する小水路および自然河川にお ける新流速公式, 土木学会誌, 第 28 巻第 4 号, 昭 17.7 , pp. 1-29.

14）久宝雅史：砂利河川の工法に関する 水理学的研究, 学位 論文 (京都大学), 昭 33.2, pp. 121-149.

15) Liu, H.K. \& Hwang, S.Y. : Discharge Formula for Straight Alluvial Channels; Proc. ASCE, HY 11, Nov. 1959, pp. 65-97.

16) Simons, D.B. \& Albertson, M.L. : Uniform Water Conveyance Channels in Alluvial Material, Proc. ASCE, Vol. 86, No. HY 5, May 1960, pp. 33-71.

17) Garde, R.J. \& Ranga Raju, K.G. : Resistance Relationships for Alluvial Channel Flow, Proc. ASCE, Vol. 92, No. HY 4, July 1966, pp. 77-100.

18）文献 16) に同じ

19）文献 13）に同じ

20) Simons, D.B. : Theory and Design of Stable Channels in Alluvial Materials, Thesis for the Degree of Doctor of Philosophy, Colorado State University, May 1957, pp. 380-391.

21）九州地方建設局編 : 粗度係数実測資料集, 1955, pp. 122135.

22）文献 9）に同じ

23）建設省河川局計画課編：粗度係数の資料， 1955.

24）文献 20) に同じ, pp. 378-379.

25) Kellerhals, R.: Stable Cannels with Gravel-paved Beds, Proc. ASCE, Vol. 93, No. WW 1, Feb. 1967, p. 70 .

26）富永正義 : 常願寺川改修計画について, 土木学会誌, 第 22 巻第 8 号, 昭 11.8, p. 740 .

27) 井口昌平: 砂れき堆の形成に関する 水理学的考察, 東大 生産技術研究所報告, 第 14 巻第 5 号, 1965, p. 316 .

28）文献 5) に同じ

29) Garde, R.J. \& Ranga Raju, K.G. : Regime Criteria for Alluvial Streams, Proc. ASCE, Vol. 89, No. HY 6, Nov. 1963, pp. 77-100.

30）杉尾捨三郎: 冲積河川の河床状態の区分法, 第 20 回中四 国土木学会講演会概要集, I - 12 , 昭 43,7 .

31) Task Committee on Sedimentation of the Hydraulics Division : Sediment Transportation Mechanics, Introduction \& Properties of Sediment, Proc. ASCE, Vol. 88, No. HY 4, July 1962, pp. 77-107.

32） 中国地建斐伊川工事々務所編: 斐伊川の 粗度係数につい $\tau$, 昭 31-10.

33) Simons, D.B. \& Richardson, E.V. : Resistance to Flow in Alluvial Channels, Geological Survey Professional Paper, 442-J, 1966, p. 7.

34）木下良作 : 石狩川河道変遷調査, 参考編, 科学技術庁資 源局資料第 36 号, 昭 37,12, pp. 73-96.

35）岩垣雄一: 限界掃流力の 流体力学的研究, 土木学会論文 集, 第 41 号, 1956, pp. 1-21.

36）杉尾捨三郎：均一粒砂の掃流砂量について, 第 23 回土木 学会年次講演会, II-115, 昭 43.10, pp. 313-314.

37）文献 2) に同じ, p. 17.

38）文献 31) に同じ, p. 95.

39）須賀克三: 河川の粗度に関する䧱考, 土木技術資料, 第 7 巻, 第 6 号, 昭 40,6, p. 83.

40) Chow, V.T. : Open-Channel Hydraulics, Mc Graw Hill Book Co. Inc., New York, p. 105.

a）本論文の一部はつぎの論文に略述した. 杉尾捨三郎：河川の平均流速公式について，第 13 回土木 学会水理研究会講演集, II-16, 昭 44.2, pp. 79-84.

(1969.3.17 - 受付) 